\title{
Determinants of access to improved water sources: Meeting the MDGs
}

\author{
Micaela Antunes, Rita Martins \\ CeBER and Faculty of Economics, University of Coimbra, Portugal
}

\section{A R T I C L E I N F O}

\section{JEL classification:}

C23

$\mathrm{O} 15$

Q25

Keywords:

The human right to water

Improved water sources

Development goals

\begin{abstract}
A B S T R A C T
Formally acknowledged in 2010, the human right to water reveals an increasing commitment to guaranteeing the universality of access to water for domestic uses, in accordance to the targets set in both the Millennium Development Goals and Sustainable Development Goals. However, countries' fulfillment of the goal to provide access to improved water sources varies. Investing in infrastructures or education and promoting women's access to formal jobs are expected to increase the access to improved water sources, especially in more urbanized areas.
\end{abstract}

\section{Introduction}

The human right to water was recognized as a human right in 2010 by the United Nations (UN). Its Resolution 64/292 (UN, 2010) acknowledged that clean drinking water and sanitation are essential to the fulfillment of all human rights. This was not, however, the first time that the UN showed concern for this issue. Already in 2002, through the General Comment no. 15 adopted by the Committee on Economic, Social and Cultural Rights (UN, 2002), the right to water was acknowledged as being essential for the dignity of human life and as a requirement for the achievement of other human rights. The right to water was then defined as "Everyone's right to have access to sufficient, safe, acceptable and physically accessible and affordable water for personal and domestic uses".

The right to water encompasses only personal and domestic purposes, thus leaving out the use of water for farming or livestock grazing. This has consequences for water management, due to the priority given to the satisfaction of personal and domestic water needs, which represents about $5 \%$ of total water needs, when compared to irrigation that accounts for more than $80 \%$ of water consumption in developing countries (UNHR, UNHabitat, WHO, 2010).

Goal 7 of the eight Millennium Development Goals (MDGs) to eradicate extreme poverty is about ensuring environmental sustainability. Target 7.C was set to halve, by 2015, the proportion of the population without sustainable access to safe drinking water and basic sanitation. The expectation was that the target would be achieved worldwide.
Safe drinking water is a relative term, varying with country and international organizations' specific quality standards and guidelines (Dinka, 2018). Even in the core of the UN, the interpretation of safe water has evolved. The indicator proposed to assess the fulfilment of Target 7.C was the percentage of population with access to an improved water source (iws). An iws is one that adequately protects the source from outside contamination, particularly fecal matter with ready access to water for domestic purposes.

However, access to an improved water source is more about ensuring the availability of an essential quantity of water nearby (according to the Joint Monitoring Program, availability of at least $20 \mathrm{~L}$ per person per day from an improved source within $1 \mathrm{~km}$ from the user's dwelling) than to guaranteeing that the water is safe or adequate for human consumption. One cannot thus ensure that there is a direct link between an improved water source and water quality (Smiley, 2017). According to Patunru (2015), improved water sources do provide some degree of additional protection over unimproved sources, despite the fact that microbial quality cannot be guaranteed (Shaheed et al., 2014). In fact, the definition of improved sources does not consider aspects such as physico-chemical contamination and insufficient mineral quality.

Even though remarkable progress has been achieved, in 2015 the United Nations General Assembly reassumed under the Sustainable Development Goals (SDGs) the need to ensure the availability and sustainable management of water and sanitation for all - Goal 6, under the specific Target 6.1, which stated the achievement of universal and equitable access to safe and affordable drinking water for all by 2030 . The indicator proposed to monitor this target was the percentage of

\footnotetext{
* Corresponding author. Faculty of Economics, University of Coimbra, Av. Dias da Silva, 165, 3004-512 Coimbra, Portugal.

E-mail address: rvmartin@fe.uc (R. Martins).
} 
population using safely managed water $(s m w)$. This concept is more demanding than iws in the sense that water sources must be located on premises, available when needed and free from fecal and priority chemical contaminations. This partly justifies the controversy in the interpretation of the accomplishment of the MDG7's Target 7.C, which is thoroughly discussed for example by Tortajada and Biswas (2018), Martinez-Santos (2017) and Guardiola et al. (2010). Recently, Brown et al. (2016) have stressed that the design of SDGs is extremely important from a public policy standpoint, due to its contribution to the creation of a new international climate where all eyes are set on ensuring water and sanitation provision for the most vulnerable, promoting integrated growth and fighting poverty on all fronts. Promoting human right to water must thus be balanced by the need to guarantee economic sustainability in water provision. Nevertheless, policy makers may give priority to grant access to water to the most vulnerable populations, at the cost of economic and financial sustainability (Schmidt and Matthews, 2018).

Water crises, understood as the result of a significant decline in the available quality and quantity of fresh water, with negative consequences for human health and/or the economy, are currently perceived as the 4th global risk (out of a list of thirty, from several domains: economic, environmental, geopolitical, societal and technological) in terms of negative impact within the next 10 years (WEF, 2019). This fact justifies per se the need to intervene in the promotion of the human right to water.

Despite the growing awareness about the urgency of providing access to water to those most in need and the progresses observed over the last years, this right is far from being fulfilled worldwide (Tortajada and Biswas, 2017). It must be stressed, however, that the analysis of the access to water cannot be reduced to a dichotomy "success versus failure", as it is more enriching if it is centered on the (sometimes conflicting) interactions between Government and both formal and informal stakeholders involved in the process (Angel and Loftus, 2019). It is urged that short-term measures or rhetorical discussions be replaced by pilot projects adjusted to local contexts and available resources, promoting cooperation and dialogue among the different stakeholders and the replication of the best practices and methodologies when possible (Ravet and Brailowsky, 2014). Moreover, the pursuit of the human right to water will hardly develop into an even configuration of universal access in practice. In fact, there are major differences across world regions and the fact is that countries - and world regions - are at different stages regarding the fulfillment of this right. Instead, successes and failures coexist, regarding the conversion of the human right to water into policy practice (Yates and Harris, 2018).

There are more vulnerable groups when it comes to access to water. One example is the rural poor, representing the majority of those deprived of the human right to water. On the other hand, urban poor living in slums also face challenges in this regard, due to the reluctance of authorities and service suppliers to connect slums to the water and sanitation networks because they are informal settlements (UNHR, UNHabitat, WHO, 2010).

Women are also considered more exposed to discrimination when it comes to the human right to water. In fact, women and children are often in charge of collecting water when it is not available in their home, which mostly implies walking long distances and spending many hours a day carrying out this task. Consequently, they are often unable to attend school, which can explain the on-going gender gap and the difficulty to empower women in developing countries. In addition, health problems are directly linked to the lack of access to improved water sources and the need to collect it far from home (UNHR, UNHabitat, WHO, 2010).

The purpose of this paper is twofold: (i) to analyze the performance regarding the access to water over time and across regions; and (ii) to identify the main determinants of access to an improved water source, used to monitor MDG7's Target 7.C, which to some extent can be understood as a proxy for the fulfillment of the human right to water. The analysis focuses on those countries that struggle the most to meet the thresholds considered appropriate in terms of water supply goals, according to the literature.

From the above, we will focus on physical accessibility, one of the basic service parameters usually considered to evaluate the adequacy of the supply of drinking water, which also include quality, quantity, affordability and continuity (WHO, 2017). These parameters are interrelated and to fulfill the most demanding ones first it is necessary to ensure that access is guaranteed. Countries at different development stages face different challenges. Prior to conceiving policies oriented to the fulfilment of affordability and quality issues or to avoid disconnection of supply it is necessary to ensure physical accessibility. Although the right to water has been clearly recognized worldwide, there are still inequalities in terms of access to safe drinking water across and within countries. Granting access to water for personal and domestic uses does not mean the same in countries in different development stages.

For developed countries, where physical access is generally granted, it is more a question of affordability (Martins et al., 2019), whereas in less developed countries, the central issue is about the building of infrastructures that ensure population's access to potable water. Physical scarcity is more likely to be found in developing countries, whereas in developed economies the problem is in economic scarcity (Dinka, 2018).

The ratio of the population with reliable access to safe drinkingwater is considered to be the most important single indicator of the overall success for the supply of drinking water under a public health policy (WHO, 2017). There is no consensus in defining access (or coverage), but in the framework of the MDGs, access to safe drinking water is measured by the WHO/United Nations Children's Fund (UNICEF) Joint Monitoring Program for Water Supply and Sanitation (JMP) using a proxy that assesses the use of improved water sources by households. Accordingly, an improved drinking-water source is considered to be one that by the nature of its construction and design adequately protects the source from fecal contamination.

The remainder of the paper is structured as follows. Section 2 presents the data used and the methodology adopted. In Section 3, the results are presented and discussed. Finally, Section 4 draws some conclusions and provides policy implications.

\section{Data and methods}

International organizations are currently committed to promoting awareness about the need to guarantee access to safe water, especially by more vulnerable groups. Despite involving huge financial costs in terms of infrastructures and education, economic returns are expected to be at least triple than the value invested in water and sanitation, according to the World Health Organization.

Access to water is affected by several factors and so it must be analyzed from a multidimensional perspective. As a proxy for human right to water, the proportion of the population that has access to an improved water source (iws) is used, thus measuring the share of the population with ready access to water for domestic purposes.

Improved water sources include piped water on premises (piped household water connection located inside the user's dwelling, plot or yard) and other improved drinking water sources, such as public taps or standpipes, tube wells or boreholes, protected dug wells, protected springs, and rainwater collection.

In order to look into the factors which may have an impact over access to improved water sources, we collected information for the period 1990-2015, where data was available, for variables from several dimensions: economic, socio-demographic, educational and political. ${ }^{1}$

According to the literature (Krause, 2009), we consider only those countries with a national coverage of water supply services below $95 \%$ for signaling those cases where the human right to water is more

\footnotetext{
${ }^{1}$ To avoid at the most having incomplete series in key variables, linear interpolation is used (ipolate in Stata 15.1).
} 
probably jeopardized.

The availability of water resources is taken into account when grouping countries according to the World Bank's definition of regions. Accordingly, countries are combined according to similar regional characteristics, namely in terms of weather conditions and consequent availability of water resources.

To research the influence of economic characteristics, we consider two kinds of potential determinants: the share of investment ( $g c f)$ and of the value added of agriculture in gross domestic product ( $a g r_{-} v a$ ). We use the former to capture investment in infrastructures. It would be preferable to focus on specific investments in water and sanitation, but a significant amount of missing observations prevents us from following that path. Unlike Dávalos (2016), we do not use financial aid as a proxy for investment, given that some of the countries are high and middle-upper economies that do not rely on this financial aid. Therefore, gross capital formation is considered to be a more reasonable proxy for investment. Large-scale investments in water and sanitation infrastructures should be carefully considered, in articulation with the individuals directly affected by such initiatives, to ensure that resources are efficiently allocated. Moreover, it is vital to target resources towards those most in need to ensure that poor households can afford water and sanitation services (de Albuquerque, 2012).

To capture the relative importance of economic sectors of activity, we use the share of the value added of agriculture in the country's gross domestic product ( $a g r_{-} v a$ ). The share of the agricultural value added as a percentage of GDP reflects the country's productive structure, being agriculture relatively more relevant for growth in early stages of economic development. A higher share is in principle associated with a lower development level and thus to lower access to improved water sources. In fact, the agricultural sector is relatively more important in less developed countries, where access to iws is not fully guaranteed. Moreover, it is acknowledged that agriculture is by far the largest user of water resources, although increasingly countries are using wastewater for irrigation.

Given that many of the economies considered in the study are defined as low-income countries by the World Bank, per capita GDP is not the most adequate indicator to capture economic activity, given certain countries' structural characteristics related to the high weight of informal economy (93 per cent of the world's informal employment is in emerging and developing countries - ILO, 2018). GDP figures only consider the exchange of goods and services that are traded in the market, thus ignoring barter trade, self-consumption, unpaid family services, smuggling, among others. These out-of-market activities are more intense in less developed economies and GDP may be thus underestimated.

In the socio-demographic domain, we consider vulnerable female employment (vuln_empl_fem), enrolment in primary education (enrol_prim_gross) and the share of urban population (urban_pop).

Vulnerable employment in the female context (vuln_empl_fem) represents the share of contributing family workers and self-employed workers (staffless own-account workers) contributing to the household income in total employment. A high proportion may be a sign of an economy relying on a large agricultural sector and presenting a modest growth in the formal economy. Moreover, a high proportion of contributing family workers - generally unpaid - may indicate the existence of weak development, as well as small job growth and a large rural economy. Vulnerable groups are considered to be most likely to fall into poverty due to the lack of formal work contracts or social protection against economic shocks. Our focus on the female segment of the population is justified by the fact that women are usually responsible for collecting water and generally have unequal opportunities, namely in the labor market. This explanatory variable aims at capturing gender inequalities. On the other hand, it also relates to Goal 1 of the MDGs Eradicate extreme poverty and hunger, Target 1.B. - Achieve full and productive employment and decent work for all, including women and young people. The concern with underprivileged groups such as women and younger is explicitly set within this Target, being monitored through the proportion of own-account and contributing family workers in total employment.

The ratio of gross enrollment in primary education (enrol_prim_gross) represents the share of persons, regardless of age, enrolled in primary education, in terms of the population of the age group that officially corresponds to this level of education. A high ratio may reflect an expressive number of overage persons enrolled either due to repetition or late entry.

The share of urban population in total (urban_pop) is also considered. The idea is that the higher this ratio, the greater the incentive to invest in water and sanitation facilities. Rural populations normally live further apart. Moreover, moving from a rural to an urban area is commonly associated with a change in the relative importance of the sectors of activity, from agriculture to industry and services.

In the political field, the variation in political stability and absence of violence and terrorism (var_pol_stab) is computed through the ranking designed by Kaufmann et al. (2010) to capture perceptions about the likelihood of politically-driven political instability and/or violence. A percentile rank was constructed, showing each country's relative position in the rank, ranging from 0 (lowest rank) to 100. The variation in this rank is used as an explanatory variable, to evaluate how developments in people's perceptions about the impact of political stability impact over iws.

The variables used in our analysis are described in Table 1.

To research which indicators are affecting access to improved water sources and how, the following regression model for panel data is considered, given by equation (1):

$$
\begin{aligned}
& i w s_{i t}=\beta_{0}+\beta_{1} g c f_{i, t-1}+\beta_{2} a g r_{-} v a_{i, t-1}+\beta_{3} v u{\ln \_e m p l \_f e m_{i, t-1}+} \\
& \beta_{4} \text { enrol_prim_gross }_{i, t-1}+\beta_{5} \text { urban }_{-} \text {pop }{ }_{i, t-1}+\beta_{6} \text { var_pol_stab }_{i, t-1}+\beta_{7} m d g+ \\
& \sum \beta_{k} \text { mdg*region }{ }_{k}+u_{i}+\varepsilon_{i, t}
\end{aligned}
$$

With our linear multivariate regression model we assess the marginal impact of each regressor over the conditional mean of the dependent variable, ceteris paribus, thus highlighting the causal relationships between the explanatory and the dependent variables.

The index $i$ is for countries and $t$, for time. $u_{i}$ stands for countryspecific effects capturing differences among economies (countries) and $\varepsilon_{i, t}$ is the idiosyncratic error term. In case the regressors are correlated

\begin{tabular}{|c|c|c|}
\hline Variable & Description & Database \\
\hline iws & $\begin{array}{l}\text { Improved water source (\% of } \\
\text { population with access) }\end{array}$ & $\begin{array}{l}\text { Millennium Development } \\
\text { Goals (data extracted on } \\
\text { April 25th, 2018) }\end{array}$ \\
\hline$g c f$ & $\begin{array}{l}\text { Gross capital formation (\% of } \\
\text { GDP) }\end{array}$ & $\begin{array}{l}\text { Millennium Development } \\
\text { Goals (data extracted on } \\
\text { April 25th, 2018) }\end{array}$ \\
\hline$a g r_{-} v a$ & $\begin{array}{l}\text { Agriculture, value added ( } \% \text { of } \\
\text { GDP) }\end{array}$ & $\begin{array}{l}\text { World Development } \\
\text { Indicators (data extracted on } \\
\text { April 25th, } 2018\end{array}$ \\
\hline vuln_empl_fem & $\begin{array}{l}\text { Vulnerable employment, female } \\
\text { (\% of female employment) }\end{array}$ & $\begin{array}{l}\text { Millennium Development } \\
\text { Goals (data extracted on } \\
\text { April 25th, 2018) }\end{array}$ \\
\hline enrol_prim_gross & $\begin{array}{l}\text { Gross enrolment ratio (\% of } \\
\text { students enrolled in primary } \\
\text { education - regardless of age - in } \\
\text { terms of the population of the age } \\
\text { group that officially corresponds } \\
\text { to primary education) }\end{array}$ & $\begin{array}{l}\text { World Development } \\
\text { Indicators (data extracted on } \\
\text { April 25th, 2018) }\end{array}$ \\
\hline urban_pop & $\begin{array}{l}\text { People living in urban areas ( } \% \text { of } \\
\text { total) }\end{array}$ & $\begin{array}{l}\text { Sustainable Development } \\
\text { Goals (data extracted on } \\
\text { April 19th, 2018) }\end{array}$ \\
\hline pol_stab & $\begin{array}{l}\text { Political stability and absence of } \\
\text { violence/terrorism (percentile } \\
\text { rank) }\end{array}$ & $\begin{array}{l}\text { Worldwide Governance } \\
\text { Indicators (data extracted on } \\
\text { April 23rd, 2018) }\end{array}$ \\
\hline
\end{tabular}

Table 1

Variables description and data sources. 
with the $u_{i}$, (then) the Fixed Effects (FE) estimator is consistent while the Random Effects (RE) estimator is not. On the contrary, if the regressors are not correlated with the, $u_{i}$ then the FE estimator, although consistent, is inefficient, whereas the RE estimator is both consistent and efficient (Baum, 2006). After estimating the model by both methods and performing the Hausman test, the results point to the rejection of the null hypothesis, which states that the difference in coefficients from both models is not systematic $-\chi_{12}^{2}=61.74$ (pvalue 0.000 ). The implication is that the state-level individual effects appear to be correlated with the regressors and the $\mathrm{FE}$ estimator is more appropriate for returning consistent estimates. In addition, FE estimates are usually considered more adequate for policy inferences directly related to the sample being analyzed, when compared to RE (Wooldridge, 2009).

The dependent variable is the percentage of people in a country with access to improved water sources (iws). The independent variables are the share of gross capital formation $\left(g c f_{i, t-1}\right)$, the share of agricultural value added in GDP $\left(a g r_{-} v a_{i, t-1}\right)$, the share of vulnerable employment in the female population (vuln_empl_fem ${ }_{i, t-1}$ ), the gross enrollment in primary education (enrol_prim_gross $i, t-1$ ), the share of urban population (urban_pop ${ }_{i, t-1}$ ) and the progress in the rank of political stability (var-pol_stab $\left._{i, t-1}\right)$. The explanatory variables are all lagged once to capture initial conditions and to (more likely) avoid correlation with the error term. We expect the estimated signs of the coefficients to be as follows: $\beta_{1}, \beta_{4}, \beta_{5}, \beta_{6}>0 \beta_{2}, \beta_{3}<0$ and $\beta_{2}, \beta_{3}<0 \beta_{1}, \beta_{4}, \beta_{5}, \beta_{6}>0$

A binary variable accounting for the influence of setting the MDGs ( $m d g$ ) is included in the model (= 1 from 2000 onwards), to be combined with regional effects, accounted for by including a dummy variable for each region, to capture regional specificities regarding climate, topology, and other geographic characteristics common to each region's group of countries (region $k$, with $k=$ East Asia and Pacific, Europe and Central Asia, Latin America and the Caribbean, Middle East and North Africa, South Asia and Sub-Saharan Africa - the last is the base group). We make no preliminary considerations about the signs of the coefficients associated to the interaction between the MDGs design and each of the regions.

A final note to take account of the possible limitations inherent to this type of model. Due to aspects beyond the control of researchers (e.g. unobserved or unavailable data), which are included in the error term, the model cannot fully capture reality. The decision to include a given variable in the theoretical model follows the related literature, with the implicit trade-off between including more variables (at the cost of possibly including some irrelevant variables that lead to a loss of precision in the estimates) or using less variables (with the consequence being the risk of having biased estimates, when the omitted variables are relevant).

\section{Results and discussion}

Developments in the proportion of world population without access to improved water sources during 1990-2015 are displayed in Fig. 1. This ratio ranges from about 20 to $11 \%$, from the beginning and until the end of the period, corresponding to about one billion people without access to improved water sources (de Albuquerque, 2012). The most recent data thus highlights the fact that almost $90 \%$ of the world's population has access to improved water sources. From 2000 to 2015 (the period during which the MDGs were monitored) there was a reduction of about $37 \%$ in the share of the World's population which did not have access to improved water sources, thus demonstrating significant progress in this area.

The global effort to meet Target 7.C of the MDGs is thus evident, although the data released by the UN about the fulfillment of the Target 7.C has been criticized in the literature, greatly due to the connection made between outcomes in access to improved water sources and water quality, when in fact these concepts are distinct (Guardiola et al., 2010; Smiley, 2017; Martinez-Santos, 2017; Tortajada and Biswas, 2018).

$$
25
$$

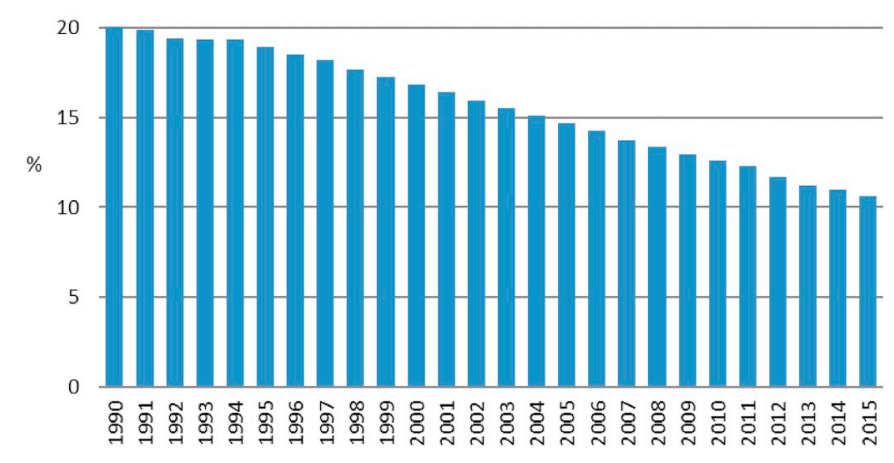

Fig. 1. Proportion of world population without access to improved water sources, 1990-2015.

Data source: Own elaboration based on data from the Millennium Development Goals Database.

Moreover, we may also argue that the performance in terms of access to improved water sources leaves out from the debate, for instance, the question of the affordability of the service. In fact, although this aspect is present in the definition, in 2010, of the human right to water as everyone's right to have access to sufficient, safe, acceptable and physically accessible and affordable water for personal and domestic uses, it was not accounted for in the definition of the MDGs, at least explicitly.

Despite all progresses, it should be noticed that significant economic, geographical and sociocultural inequalities subsist in the present, not only between rural and urban areas but also in towns (Allen and Bell, 2011), where people living in low-income, informal, or illegal settlements usually have less access to improved sources of drinking water than other residents (UNICEF and WHO, 2019). Thus, the appropriate solutions for a specific context do not necessarily succeed in another territory (Schmidt and Matthews, 2018).

As it can be seen in Fig. 2, there are major worldwide differences across regions in terms of access to improved water sources. Data from 2015 shows, on one end, North America, with only $0.5 \%$ of population without access to improved water sources, whereas, on the other end, the Sub-Saharan Africa region appears with more than one quarter (26\%) of the population excluded from access to improved water sources.

Table 2 shows the distribution of countries with less than $95 \%$ of the population with access to improved water sources, across regions.

From 1990 to 2015, there are 142 countries that display at least once a national coverage of water supply services below $95 \%$. Out of these, about $1 / 3$ are from Sub-Saharan Africa. This is the region with the worst

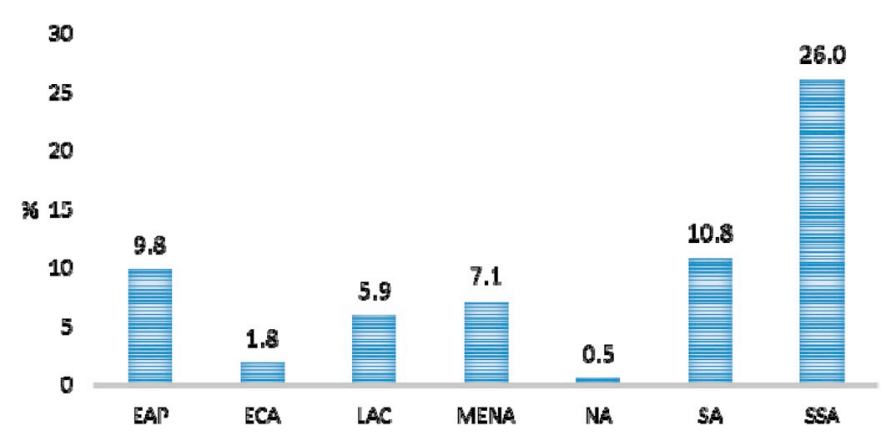

Fig. 2. Proportion of population without access to improved water sources, 2015 (by region).

Data source: Own elaboration based on data from the Millennium Development Goals Database. Note: EAP - East Asia and Pacific; ECA - Europe and Central Asia; LAC - Latin America and Caribbean; MENA - Middle East and North Africa; NA - North America; SA - South Asia; SSA - Sub-Saharan Africa. 
Table 2

Distribution of sample countries with iws < 95\% (per region), 1990-2015.

\begin{tabular}{llll}
\hline Region & \# Countries & Average iws (\%) & Min \\
\hline EAP & 26 & 76.3 & 23.4 \\
ECA & 14 & 83.7 & 57.2 \\
LAC & 33 & 86.5 & 53.0 \\
MENA & 15 & 83.0 & 54.3 \\
NA & 0 & - & - \\
SA & 8 & 76.5 & 21.2 \\
SSA & 46 & 62.3 & 13.2 \\
Total & 142 & 74.4 & 13.2 \\
\hline
\end{tabular}

records regarding access to improved water sources, with an average of $62.3 \%$ over the period. Besides, it is also the region showing the highest dispersion, given that it displays the lowest figure in terms of proportion of people with access to improved water sources (13.2\%).

Fig. 3 compares general developments in average iws by region, from 1990 to 2015, for the sample of countries considered.

We can detect the existence of three groups: (i) one group formed by ECA, LAC and MENA regions, with the highest ratios and the most discrete performances during the period; (ii) EAP and SA, with intermediate figures, the latter displaying clear progress, joining the regions from the first group in the more recent period; (iii) the SSA region, starting with a considerably lower ratio and, despite the clear positive evolution, still the worst performing region in terms of iws in 2015.

Table 3 displays some general descriptive statistics for the 142 countries whose national coverage of improved water sources is below $95 \%$.

Given that our sample refers to countries with ratios of access to improved water sources below $95 \%$, the average for iws is relatively low, as expected $(74.4 \%)$. A great dispersion of data is also visible, with the lowest figure standing at $13.2 \%$.

Regarding the explanatory variables, it is possible to detect extreme values, thus showing how aggregate averages may hide different individual performances. In global terms, we have here countries with very distinct performances and it is worth exploring further such heterogeneity.

The panel data model given in equation (1) is estimated by FE by clustering on the panel variable, which produces a consistent variancecovariance estimator (VCE) when the disturbances are not identically distributed across the panels or there is serial correlation in the error term. This cluster-robust VCE requires the disturbances to be uncorrelated across the clusters. On the contrary, Driscoll and Kraay's correction of the error structure takes into account the possible existence of correlation of residuals among groups of individuals (De Hoyos and Sarafidis, 2006). With this correction, HAC (heteroscedasticity and autocorrelation consistent) standard errors are robust to general forms of temporal and spatial dependence asymptotically. Moreover, their small-sample properties are considerably better than those of alternative

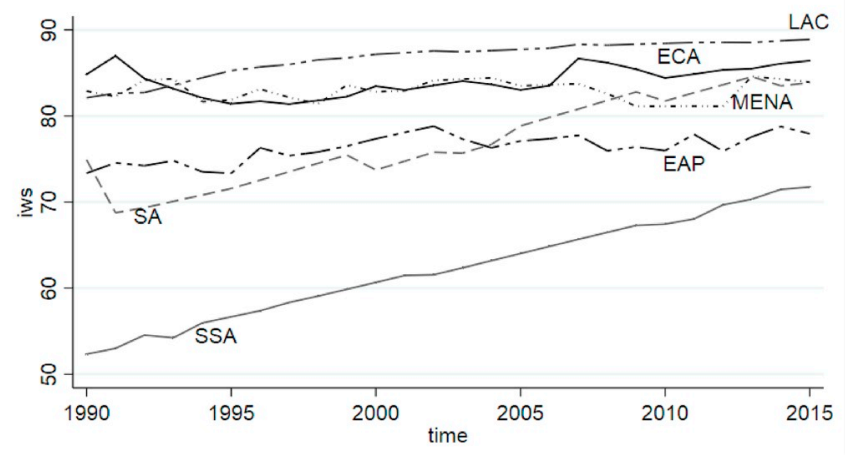

Fig. 3. Evolution of iws by region, 1990-2015, 142 countries. Note: Authors' computation using Stata 15.1 .
Table 3

Descriptive statistics of time-varying variables.

\begin{tabular}{llllll}
\hline Variable & Observations & Mean & Std. Deviation & Min & Max \\
\hline iws & 2937 & 74.4 & 17.9 & 13.2 & 94.9 \\
gcf & 2514 & 23.0 & 12.6 & 0 & 219.1 \\
agr_va & 2448 & 21.5 & 14.4 & 0.4 & 94.0 \\
vuln_empl_fem & 2630 & 58.9 & 27.0 & 0.5 & 99.2 \\
enrol_prim_gross & 2650 & 97.6 & 21.7 & 21.5 & 152.2 \\
urban_pop & 2933 & 44.1 & 20.6 & 5.4 & 100 \\
pol_stab & 2130 & 35.4 & 24.3 & 0 & 100 \\
\hline
\end{tabular}

techniques in the presence of cross-sectional dependence (Hoechle, 2007).

Given that it was not possible to perform Pesaran's test on residual cross-sectional dependence after FE regression due to lack of a sufficient number of common observations in the panel, the option was to compare outcomes from the FE with robust standard errors (1) and the FE regression with Driscoll-Kraay's correction for standard errors (2), in Table 4.

Due to missing observations, some countries were excluded from the regression, leaving us with 111 countries (list provided in the Appendix).

In the presence of spatial correlation between countries, DriscollKraay's correction provides more efficient outcomes, which may explain why some coefficients gain statistical significance, compared with the estimation results from $\mathrm{FE}$ with robust standard errors.

Given that we estimate a linear model, the interpretation of the (statistically significant) coefficients is straightforward and similar across variables (except for the binary variables). Each coefficient represents a relationship between absolute changes (in the explanatory and in the conditional mean of the dependent variable). For example, the interpretation for the coefficient of vuln_empl_fem is that if the share of vulnerable female employment increases by 1 percentage point (p.p.), it is expected that the percentage of population with access to iws

Table 4

Estimation results, 111 countries, 1991-2015.

\begin{tabular}{|c|c|c|}
\hline Variables & FE Robust (1) & Driscoll-Kraay (2) \\
\hline$g c f_{i, t-1}$ & $\begin{array}{l}0.0490 \\
(1.431)\end{array}$ & $\begin{array}{l}0.0490 * * * \\
(3.886)\end{array}$ \\
\hline$a g r_{-} v a_{i, t-1}$ & $\begin{array}{l}-0.1055^{*} \\
(-1.715)\end{array}$ & $\begin{array}{l}-0.1055^{* * *} \\
(-3.988)\end{array}$ \\
\hline$v_{\text {vuln_empl_fem }}$ i,t-1 & $\begin{array}{l}-0.1056 \\
(-1.240)\end{array}$ & $\begin{array}{l}-0.1056^{* * *} \\
(-3.244)\end{array}$ \\
\hline enrol_prim_gross $_{i, t-1}$ & $\begin{array}{l}0.0620^{*} \\
(1.830)\end{array}$ & $\begin{array}{l}0.0620 * * * \\
(6.190)\end{array}$ \\
\hline urban_pop $_{i, t-1}$ & $\begin{array}{l}0.8647^{* * * *} \\
(4.104)\end{array}$ & $\begin{array}{l}0.8647^{* * *} \\
(9.239)\end{array}$ \\
\hline$v a r_{-} p o l_{-} s t a b_{i, t-1}$ & $\begin{array}{l}0.0097 \\
(0.727)\end{array}$ & $\begin{array}{l}0.0097 \\
(1.093)\end{array}$ \\
\hline$m d g$ & $\begin{array}{l}3.3376^{* * * *} \\
(3.567)\end{array}$ & $\begin{array}{l}3.3376^{* * *} \\
(3.293)\end{array}$ \\
\hline$E A P * m d g$ & $\begin{array}{l}-0.8273 \\
(-0.448)\end{array}$ & $\begin{array}{l}-0.8273^{* * *} \\
(-4.392)\end{array}$ \\
\hline$E C A * m d g$ & $\begin{array}{l}-0.2556 \\
(-0.171)\end{array}$ & $\begin{array}{l}-0.2556 \\
(-0.339)\end{array}$ \\
\hline$L A C * m d g$ & $\begin{array}{l}-1.3953 \\
(-1.081)\end{array}$ & $\begin{array}{l}-1.3953^{* *} \\
(-2.622)\end{array}$ \\
\hline$M E N A * m d g$ & $\begin{array}{l}-4.4867^{* *} \\
(-2.073)\end{array}$ & $\begin{array}{l}-4.4867^{* * *} \\
(-3.470)\end{array}$ \\
\hline$S A^{*} m d g$ & $\begin{array}{l}-0.6957 \\
(-0.383)\end{array}$ & $\begin{array}{l}-0.6957 * * \\
(-2.805)\end{array}$ \\
\hline Constant & $\begin{array}{l}36.9561^{* * *} \\
(3.375)\end{array}$ & $\begin{array}{l}36.9561^{* * *} \\
(6.556)\end{array}$ \\
\hline F-test & 12.46 & 2801 \\
\hline p-value F-test & 0.000 & 0.000 \\
\hline $\begin{array}{l}\text { Observations } \\
R^{2} \text { within }\end{array}$ & \multicolumn{2}{|c|}{1453} \\
\hline
\end{tabular}

Notes: Robust t-statistics in parentheses.

$*, * *, * * *$ Coefficient significant at $10 \%, 5 \%$ and $1 \%$, respectively. 
decreases on average 0.11 p.p., ceteris paribus.

The signs of causality are as expected. Female vulnerable employment, which is more relevant in less developed economies, displays a significantly negative impact on the proportion of population with access to improved water sources. To enhance access to improved water sources it is thus important to promote the participation of women in the formal labor market. In fact, women are more exposed to informal employment in most low and lower-middle income countries, according to ILO (2018) being more often in the most vulnerable situations.

Given that the coefficient of the share of value added in agriculture is negative and statistically significant, it can be argued that countries whose productive structures are more concentrated in the primary sector - usually the less developed ones - face more difficulties in guaranteeing the universal access to iws.

On the contrary, gross enrollment in primary education, gross capital formation, and the ratio of urban population all have a positive effect over the percentage of people with access to improved water sources. This reveals the importance of investment, in both physical infrastructures and in education. Participation is critical for the success of water policies and education is crucial to ensure that individuals and groups are aware of participatory processes and how they function (de Albuquerque, 2014). The concentration of population in urban areas may more easily attract investments in water infrastructures. Nonetheless, ensuring that a growing urban population has access to adequate water supply in a context of changing climate conditions constitutes a huge challenge (Allen and Bell, 2011). The impact of such investments on the share of population with access to improved water sources is expected to be higher in urban contexts than in rural areas, where population is more disperse. This does not mean that efforts should not be done to ensure the highest possible coverage rates in rural areas. Through a socio-technical analysis, Narain and Singh (2017) stress precisely the importance of the involvement of communities in water projects following urbanization waves.

Although the coefficient of evolution in the political stability score is not statistically significant, the variable was kept in the regression to stress precisely that this dimension cannot be ignored. The question at this point is more of collecting data in this domain to enable more accurate estimates in the future, than to simply discard this proxy. Given our large dataset, with more than 100 countries and with a time span of more than a decade, it was hard to find enough observations for our dataset. We have also used alternatively other proxies in the regression (such as voice and accountability, governance effectiveness, regulation quality, rule of law and control of corruption, from Kaufmann et al., 2010), but the results obtained were similar to those in Table 4. Moreover, we also investigated whether the impact of the political variable was significant over greater lags, but no significant results were obtained.

While at first this outcome may seem puzzling, if we think more thoroughly, it turns out to make sense. The political performance of a country is a structural feature that does not change overnight. Moreover, the political features of a country may be perceived through the performance in other areas such as education, gender inequalities, investment in infrastructures, etc.

The design and implementation of the MDGs ( $m d g$ ) had a positive impact by itself in terms of access to iws, increasing it in about 3.34 p.p. when compared to the pre-2000 period, when conditional expected iws was, on average, $37 \%$. That impact (of 3.34 p.p.) is slightly reduced for the East Asia and Pacific, the Latin America and the Caribbean and the South Asia regions (in about $0.83,1.40$ and 0.70 p.p., respectively). For the Middle East and North Africa region, the net effect of the implementation of the MDGs is negative (in 1.15 p.p.), in comparison to SubSaharan Africa before 2000 (the reference categories), which may be justified by the destruction, in recent years, of several infrastructures due to war conflicts that constrain people's access to safe water (FAO, IFAD, UNICEF, WFP and WHO, 2017). Had this not been the case, it would be expectable that the investment share in the MENA region in recent years - triple that of SSA- would be reflected into a relatively better performance in terms of access to improved water sources (Fay et al., 2017).

\section{Conclusions}

Water is essential to life, as a requirement for a healthy population as well as for most productive activities and, consequently, for the pursuit of sustainable economic growth. Hence, growing awareness of the importance of water for human consumption, not only from an individual perspective, but also from society's standpoint, has called upon several groups of interest - both official and informal networks - to take part.

The human right to water was formally recognized by the UN in 2010, although previously attention had already been called to the importance of ensuring access to water, namely through the commitment assumed within the MDG7 to halve the proportion of the population without access to safe drinking water (Target 7.C). These concerns were explicitly reassumed within SDG6 (Target 6.1).

The fulfillment of the MDG7 was addressed in this paper by looking at the evolution of the proportion of population with access to improved water sources. Although there has been a remarkable progress in the reduction of the population without sustainable access to drinking water, universality has not been fully achieved and regional differences persist. The relative performance of the Middle East and North Africa region has even deteriorated in recent years. This means that in practice, there is the need to find suitable practices for specific territories (de Albuquerque, 2012).

The empirical analysis performed also tried to identify which factors affect the access to improved water sources, since its main determinants are important for the design of effective policies. Our findings allows us to conclude that investments in physical infrastructures, particularly in urban areas, as well as in education and the encouragement of paid employment for women all have a positive effect on the access to improved water sources. Moreover, economies of agglomeration from urban growth might provide water access to more people, as long as congestion costs do not neutralize these economies. Nonetheless, it is important to bear in mind that the human right to water and the Target 6.1 of SDG6 clearly state that universality must be accomplished. Thus, everyone has the right to have access to water, independently from living in urban or rural areas.

Active policies to reduce gender inequalities and to promote higher educational standards are expected to exert positive externalities over access to improved water sources. As Schultz, 1990; Bucciarelli et al. (2011); Pitt et al. (2012) or Bloom et al. (2017) argue, increasing investment in women's education positively affects the improvement of education of the next generation and results in a higher capability to produce human capital, compared to similar investment in men's education.

A joint action in this regard promotes active and informed participation and may contribute to achieve more effective water policies.

Countries with a large share of agriculture - usually the ones in less developed stages - are further from accomplishing higher water access ratios. This does not mean that the productive structure should be changed. Instead, this finding reveals that less developed countries need to make stronger efforts to achieve the universal water access purposes.

It is worthwhile to mention that these determinants are contextual variables, which are not under direct water policy control. In fact, it would be enriching to include variables controlled by those who are responsible for the design and implementation of water policies. A further avenue for research would be to collect and to use such type of explanatory variable. Another would be to assess determinants of other dependent variables that overcome the limitations of the iws indicator, namely in terms of water quality parameters, continuity of service and affordability issues, pointed out by several authors. 
Funding

This work has been funded by national funds through FCT -

\section{Appendix}

List of countries included in the regressions.

\begin{tabular}{|c|c|c|}
\hline Country & Region & Obs \\
\hline Afghanistan & SA & 13 \\
\hline Algeria & MENA & 18 \\
\hline Angola & SSA & 5 \\
\hline Armenia & ECA & 7 \\
\hline Azerbaijan & ECA & 18 \\
\hline Bangladesh & SA & 18 \\
\hline Belize & LAC & 11 \\
\hline Benin & SSA & 18 \\
\hline Bhutan & SA & 12 \\
\hline Bolivia & LAC & 18 \\
\hline Botswana & SSA & 4 \\
\hline Brazil & LAC & 2 \\
\hline Burkina Faso & SSA & 18 \\
\hline Burundi & SSA & 18 \\
\hline Cabo Verde & SSA & 8 \\
\hline Cambodia & EAP & 18 \\
\hline Cameroon & SSA & 18 \\
\hline Central African Rep. & SSA & 16 \\
\hline Chad & SSA & 18 \\
\hline Chile & LAC & 3 \\
\hline China & EAP & 8 \\
\hline Colombia & LAC & 18 \\
\hline Congo, Dem. Rep. & SSA & 18 \\
\hline Congo, Rep. & SSA & 15 \\
\hline Costa Rica & LAC & 2 \\
\hline Cote d'Ivoire & SSA & 2 \\
\hline Cuba & LAC & 18 \\
\hline Djibouti & MENA & 11 \\
\hline Dominican Republic & LAC & 18 \\
\hline Ecuador & LAC & 18 \\
\hline El Salvador & LAC & 18 \\
\hline Equatorial Guinea & SSA & 7 \\
\hline Eritrea & SSA & 13 \\
\hline Ethiopia & SSA & 18 \\
\hline Fiji & EAP & 12 \\
\hline Gabon & SSA & 11 \\
\hline Gambia, The & SSA & 11 \\
\hline Georgia & ECA & 10 \\
\hline Ghana & SSA & 18 \\
\hline Guatemala & LAC & 14 \\
\hline Guinea & SSA & 9 \\
\hline Guinea-Bissau & SSA & 14 \\
\hline Guyana & LAC & 13 \\
\hline Honduras & LAC & 18 \\
\hline India & SA & 14 \\
\hline Indonesia & EAP & 1 \\
\hline Iran, Islamic Rep. & MENA & 7 \\
\hline Iraq & MENA & 8 \\
\hline Jamaica & LAC & 8 \\
\hline Kazakhstan & ECA & 18 \\
\hline Kenya & SSA & 18 \\
\hline Korea, Rep. & EAP & 5 \\
\hline Kyrgyz Republic & ECA & 18 \\
\hline Lao PDR & EAP & 15 \\
\hline Lebanon & MENA & 10 \\
\hline Lesotho & SSA & 8 \\
\hline Liberia & SSA & 15 \\
\hline Lithuania & ECA & 12 \\
\hline Madagascar & SSA & 18 \\
\hline Malawi & SSA & 18 \\
\hline Malaysia & EAP & 5 \\
\hline Mali & SSA & 18 \\
\hline Mauritania & SSA & 18 \\
\hline Mexico & LAC & 10 \\
\hline Moldova & ECA & 18 \\
\hline
\end{tabular}


(continued)

\begin{tabular}{|c|c|c|}
\hline Country & Region & Obs \\
\hline Mongolia & EAP & 18 \\
\hline Morocco & MENA & 18 \\
\hline Mozambique & SSA & 18 \\
\hline Myanmar & EAP & 7 \\
\hline Namibia & SSA & 17 \\
\hline Nepal & SA & 18 \\
\hline Nicaragua & LAC & 14 \\
\hline Niger & SSA & 9 \\
\hline Nigeria & SSA & 17 \\
\hline Oman & MENA & 5 \\
\hline Pakistan & SA & 18 \\
\hline Panama & LAC & 18 \\
\hline Papua New Guinea & EAP & 8 \\
\hline Paraguay & LAC & 15 \\
\hline Peru & LAC & 18 \\
\hline Philippines & EAP & 12 \\
\hline Romania & ECA & 11 \\
\hline Russian Federation & ECA & 3 \\
\hline Rwanda & SSA & 10 \\
\hline Senegal & SSA & 18 \\
\hline Sierra Leone & SSA & 17 \\
\hline Solomon Islands & EAP & 6 \\
\hline South Africa & SSA & 18 \\
\hline Sri Lanka & SA & 16 \\
\hline St. Lucia & LAC & 8 \\
\hline Sudan & SSA & 13 \\
\hline Suriname & LAC & 18 \\
\hline Swaziland & SSA & 18 \\
\hline Syrian Arab Republic & MENA & 11 \\
\hline Tajikistan & ECA & 17 \\
\hline Tanzania & SSA & 18 \\
\hline Thailand & EAP & 9 \\
\hline Timor-Leste & EAP & 14 \\
\hline Togo & SSA & 18 \\
\hline Trinidad and Tobago & LAC & 12 \\
\hline Tunisia & MENA & 11 \\
\hline Turkey & ECA & 2 \\
\hline Uganda & SSA & 18 \\
\hline Uzbekistan & ECA & 15 \\
\hline Vanuatu & EAP & 18 \\
\hline Venezuela, RB & LAC & 16 \\
\hline Vietnam & EAP & 2 \\
\hline West Bank and Gaza & MENA & 15 \\
\hline Yemen, Rep. & MENA & 13 \\
\hline Zambia & SSA & 4 \\
\hline Zimbabwe & SSA & 17 \\
\hline Total & & 1453 \\
\hline
\end{tabular}

Distribution of the countries included in the regressions, by region.

\begin{tabular}{ll}
\hline Region & \# Countries in the regression \\
\hline EAP & 15 \\
ECA & 13 \\
LAC & 23 \\
MENA & 11 \\
SA & 7 \\
SSA & 42 \\
Total & 111 \\
\hline
\end{tabular}

\section{References}

Allen, A., Bell, S., 2011. Glass half empty? Urban water poverty halfway through the decade of water for life. Int. J. Urban Sustain. Dev. 3 (1), 1-7.

Angel, J., Loftus, A., 2019. With-Against-and-Beyond the human right to water. Geoforum 98, 206-2013. https://doi.org/10.1016/j.geoforum.2017.05.002.

Baum, C., 2006. An Introduction to Modern Econometrics Using Stata. Stata Press, Texas.

Bloom, D., Kuhn, M., Prettner, K., 2017. Invest in women and prosper. Finance and development. Int. Monet. Fund 54 (3). September. https://www.imf.org/external/ pubs/ft/fandd/2017/09/bloom.htm.

Brown, C., Neves-Silva, P., Heller, L., 2016. The human right to water and sanitation: new perspective for public policies. Ciência Saúde Coletiva 21 (3). https://doi.org/ 10.1590/1413-81232015213.20142015. March.
Bucciarelli, E., Muratore, F., Odoarbi, I., Pagliari, C., 2011. Is it possible to define gender effects of the human capital on the processes of well-being? Procedia Soc. Behav. Sci. $15,1067-1075$.

Dávalos, M., 2016. Socioeconomic indicators as determinants for water access in rural areas of developing countries: a panel data approach. Bachelor Degree Thesis. Universitat Autònoma de Barcelona. https://ddd.uab.cat/pub/tfg/2016/160484/TF G_mgomezdavalos.pdf.

de Albuquerque, C., 2012. On the Right Track: Good Practices in Realizing the Rights to Water and Sanitation. ERSAR, Lisbon. March. https://www.ohchr.org/documents/ issues/water/bookongoodpractices en.pdf.

de Albuquerque, C., 2014. Realising the human rights to water and sanitation: a handbook by the UN special rapporteur Catarina de Albuquerque - booklet 1 . Introduction. UN-OHCHR, Lisboa. https://unhabitat.org/books/realising-the-hu 
man-rights-to-water-and-sanitation-a-handbook-by-the-un-special-rapport eur-catarina-de-albuquerque/.

De Hoyos, R., Sarafidis, V., 2006. Testing for cross-sectional dependence in panel-data models. STATA J. 6 (4), 482-496. https://www.stata-journal.com/sjpdf.html?artic lenum $=$ st0113.

Dinka, Megersa Olumana, 2018. Safe drinking water: concepts, benefits, principles and standards. March 21st. In: Water Challenges of an Urbanizing World. Matjaž Glavan, IntechOpen. https://doi.org/10.5772/intechopen.71352. Available from: https: //www.intechopen.com/books/water-challenges-of-an-urbanizing-world/safe-drin king-water-concepts-benefits-principles-and-standards.

Fay, M., Andrés, L.A., Fox, C., Narloch, U., Straub, S., Slawson, M., 2017. Rethinking Infrastructure in Latin America and the Caribbean: Spending Better to Achieve More. Directions in Development. World Bank, Washington, DC. https://openknowledge. worldbank.org/bitstream/handle/10986/27615/9781464811012.pdf?sequen $\mathrm{ce}=2 \&$ isAllowed $=\mathrm{y}$.

Guardiola, J., González-Gómez, F., Grajales, A.L., 2010. Is access to water as good as the data claim? Case study of Yucatan. Int. J. Water Resour. Dev. 26 (2), 219-233. https://doi.org/10.1080/07900621003655692.

Hoechle, D., 2007. Robust standard errors for panel regressions with cross-sectional dependence. STATA J. 7 (3), 281-312. http://fmwww.bc.edu/repec/bocode/x/xt scc_paper.

ILO, 2018. Women and Men in the Informal Economy: a Statistical Picture, third ed. International Labour Office, Geneva https://www.ilo.org/wcmsp5/groups/public/ —dgreports/—dcomm/documents/publication/wcms_626831.pdf.

Kaufmann, D., Kraay, A., Mastruzzi, M., 2010. The worldwide governance indicators: methodology and analytical issues. World Bank Policy Research Working Paper No. 5430. http://papers.ssrn.com/sol3/papers.cfm?abstract id=1682130.

Krause, M., 2009. The Political Economy of Water and Sanitation. Routledge, New York.

Martinez-Santos, P., 2017. Does $91 \%$ of the world's population really have "sustainable access to safe drinking water"? Int. J. Water Resour. Dev. 33 (4), 514-533. https:// doi.org/10.1080/07900627.2017.1298517.

Martins, R., Quintal, C., Antunes, M., 2019. Making ends meet: actual versus potential joint affordability of utility services. Util. Pol. 56, 120-126. https://doi.org/10.101 6/j.jup.2018.12.002.

Narain, V., Singh, A., 2017. Flowing against the current: the socio-technical mediation of water (In)security in periurban Gurgaon, India. Geoforum 81, 66-75. https://doi. org/10.1016/j.geoforum.2017.02.010.

Patunru, A.A., 2015. Access to safe drinking water and sanitation in Indonesia. Asia Pacific Policy Stud. 2, 234-244. https://doi.org/10.1002/app5.81.

Pitt, M., Rosenzweig, M., Hassan, N., 2012. Human capital investment and the gender division of labor in a brawn-based economy. Am. Econ. Rev. 102 (7), 3531-3560. https://doi.org/10.1257/aer.102.7.3531.
Ravet, S., Braillowsky, A., 2014. Utilities' contribution to the human right to water and sanitation: importance of stakeholders' ownership. Aqua. Procedia 2, 70-78. https:// doi.org/10.1016/j.aqpro.2014.07.011.

Schmidt, J., Matthews, N., 2018. From state to system: financialization and the water energy-food-climate Nexus. Geoforum 91, 151-159. https://doi.org/10.1016/j. geoforum.2018.03.001.

Schultz, T., 1990. Returns to Women's Education. Yale University, Economic Growth Center, New Haven, CT. Center Discussion Paper, No. 603. http://hdl.handle. net/10419/160525.

Shaheed, A., Orgill, J., Montgomery, M.A., Jeuland, M.A., Brown, J., 2014. Why 'improved' water sources are not always safe. Bull. World Health Organ. 92, 283-289. https://doi.org/10.2471/BLT.13.119594.

Smiley, S.L., 2017. Quality matters: incorporating water quality into water access monitoring in rural Malawi. Water Int. 42 (5), 585-598.

Tortajada, C., Biswas, A., 2017. Water as a human right. Int. J. Water Resour. Dev. 33 (4), 509-511. https://doi.org/10.1080/07900627.2017.1321237.

Tortajada, C., Biswas, A.K., 2018. Achieving universal access to clean water and sanitation in an era of water scarcity: strengthening contributions from academia. Curr. Opin. Environ. Sustain. 34, 21-25.

UN, 2002. General Comment No. 15. The Right to Water. UN Committee on Economic, Social and Cultural Rights, November.

UN, 2010. Resolution A/RES/64/292. United Nations General Assembly, July.

UNHR, UNHabitat, WHO, 2010. The right to Water. In: Fact Sheet N., vol. 35. United Nations, Geneva, pp. 1014-5567.

UNICEF, WHO, 2019. Progress on Household Drinking Water, Sanitation and Hygiene 2000-2017: Special Focus on Inequalities - Fact Sheet on Drinking Water. United Nations Children's Fund (UNICEF) and World Health Organization (WHO), New York.

WEF, 2019. The Global Risks Report 2019 -, fourteenth ed. World Economic Forum, Geneva, ISBN 978-1-944835-15-6.

FAO, IFAD, UNICEF, WFP, WHO, 2017. The State of Food Security and Nutrition in the World 2017: Building Resilience for Peace and Food Security. FAO, Rome. http ://www.fao.org/3/a-i7695e.pdf.

WHO, 2017. Guidelines for Drinking-Water Quality, fourth ed. World Health Organization, Geneva, ISBN 978-92-4-154995-0. incorporating the 1st addendum.

Wooldridge, J., 2009. Introductory Econometrics - a Modern Approach, fourth ed. SouthWestern CENGAGE Learning, Canada.

Yates, J., Harris, L., 2018. Hybrid regulatory landscapes: the human right to water, variegated Neoliberal water governance, and policy transfer in Cape town, South Africa, and accra, Ghana. World Dev. 110, 75-87. https://doi.org/10.1016/j. worlddev.2018.05.021. 